Article

\title{
Determination of the Suitability of Some American Grapevine Rootstocks as a New Edible Landscape Component of Vertical Gardens
}

\author{
Atilla Cakir ${ }^{1, *}$, Emrah Yalcinalp ${ }^{2}$, Ezgi Dogan ${ }^{1}$ and Alperen Meral ${ }^{3}$ \\ 1 Department of Horticulture, Faculty of Agriculture, Bingol University, Bingol 12000, Turkey; \\ ezgidogan@bingol.edu.tr \\ 2 Department of Landscape Architecture, Faculty of Forestry, Karadeniz Technical University, Trabzon 61080, \\ Turkey; yalcinalp@ktu.edu.tr \\ 3 Department of Landscape Architecture, Faculty of Agriculture, Bingol University, Bingol 12000, Turkey; \\ alperenmeral@bingol.edu.tr \\ * Correspondence: acakir@bingol.edu.tr
}

Received: 18 April 2017; Accepted: 13 July 2017; Published: 19 July 2017

\begin{abstract}
In this study, grapevine was used as the research material. This plant which epitomizes the opinion that vertical gardens can have a positive influence on human psychology with their beautiful view, e.g., the hanging gardens of Babylon about 2500 years ago. The study in question was conducted in 2016 at Bingol University, Faculty of Agriculture, the Department of Garden Plants research and application area. The offshoot growth was measured in a fertilizer experiment that formed the control, first application ( $200 \mathrm{~g} / 100 \mathrm{~L}$ water, leaf) and second application $(100 \mathrm{~g} / 100 \mathrm{~L}$ water $+20 \%$ leaf + root $)$. Moreover, the plant's footprint in the vertical area was determined. The average offshoot growth of $1103 \mathrm{P}$ American grapevine rootstock in the first and second applications was measured as $61.5 \mathrm{~cm}$ and $39.5 \mathrm{~cm}$ respectively, and it was $43.0 \mathrm{~cm}$ and 51.0 for C American grapevine rootstock. The average growth of $1103 \mathrm{P}$ and $1616 \mathrm{C}$ American grapevine in the control group was determined as $30.6 \mathrm{~cm}$ and $32.1 \mathrm{~cm}$. The average growth of both American grapevine rootstocks used in the experiment was determined to be higher for the first and second applications than the controls.
\end{abstract}

Keywords: American grapevine rootstocks; vertical garden; offshoot growth; footprint

\section{Introduction}

Grapevine, which is a significant branch of agricultural sector and a valuable plant species having accompanied humankind's journey of knowing oneself, has reached its present status by being improved in accordance with human needs with its historical importance and sacred values ascribed by many religions.

Turkey has been the cradle and center of viticulture throughout history especially because of its climatic and soil characteristics [1].

Grapevine, which already had importance because of its diversity, productivity and its support to economy for centuries, has been more popular recently especially owing to resveratrol that plays an important role to protect human body from cancer and makes it stronger against viruses and regulates gastroenteric system [2]. Apart from these, it is also possible to see grapevine figures on historical fountains and gravestones in different civilizations in the history. Finally, the idea that grapevine can be used as a vertical garden plant is partly because of the fact it was ornamentally used on stone walls in history. 
Moreover, the opportunity to find nature in cities where green-fields decrease more and more decreases because of structuring, because open spaces are not scattered equally in the city. It is possible to find large and interrelated forests and light green fields in the city edges. However, green fields are almost nonexistent in densely populated areas. Existing green fields are in small fractions scattered throughout all the city, which are the remains of ruined natural vegetation having covered large areas in the past [3]. At first, roof surfaces and yards were used to vegetate the buildings. However, the fact that front facades cover more space resulted in the vegetation of these areas, providing benefit for both the building and the environment. As a result of all these developments, the concepts of living walls, green facades and wall vegetation were developed with new researches. In a study conducted in Toronto University, a model vertical garden was built and it was determined that the amount of the energy spent for air circulation, energy consumption and cooling decreased. The same study became helpful in reducing the obstacles to the proliferation of vertical gardens such as lack of knowledge, lack of incentive for application, the obstacles based on cost, technical problems related to uncertainty and risks [4].

Accordingly, it is obvious that, in the past, especially grapevines were used in vertical gardens. Vertical garden is an idea that is as old as the cities and first appeared in Babylon 2500 years ago. King Nebuchadnezzar II had Hanging Gardens of Babylon, which are regarded as the ancestor of green walls by many people today, built. As a matter of fact, Hanging Gardens of Babylon included green roofs in addition to green walls [5].

The use of grapevine-which took a place in our lives at all points thanks to its various uses, its significance for nutrition and human health, its use in architecture and decoration in the past-in environmental planning [6] and landscaping led to the opinion that it can have a good effect on human psychology with its pleasant outlook.

Greenwalls have so many effects on environments and those who live in them. Protecting the surfaces from damages, making people mentally more comfortable and making contributions to ecologic characteristics can be accepted as the most mentioned effects. Nowadays, it is also possible to see that some vegetables can grow on greenwalls and this is really important as edible landscapes have been accepted one of the most important components of urban areas [7].

This study was conducted, in accordance with this opinion, in order to investigate the usability of grapevine as vertical garden and edible landscaping element in continental climate with minimum cost while vertical green surfaces are accepted as one of the best ways to create sustainability in especially urban areas.

\section{Material and Method}

\subsection{Material}

This study was conducted in Bingol University, Faculty of Agriculture Research and Application Area in 2016. Taking the climatic conditions of Bingol city into consideration, $1103 \mathrm{P}$ and $1616 \mathrm{C}$ American grapevine rootstocks, which are recommended for many regions in our country with continental climate, were used as vegetative material in the experiment (Figures 1 and 2).

The most common parts of the grapevines that were ornamentally used in figures on historical walls are vegetative organs. Apart from this, coverage by plants on the walls is considered the most important issue on greenwalls. Because of these two phenomena, fast growing and well known grapevines were selected as the research material. 


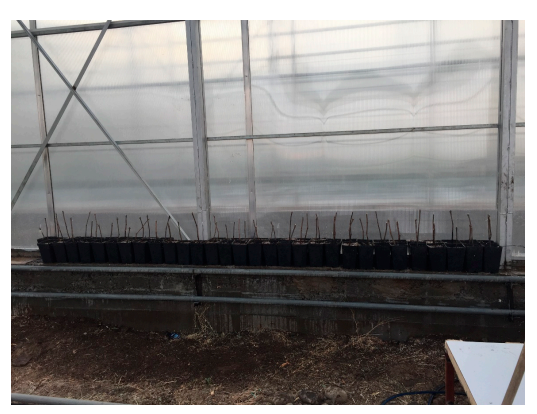

Figure 1. Cuttings taken to rooting environment in vases.

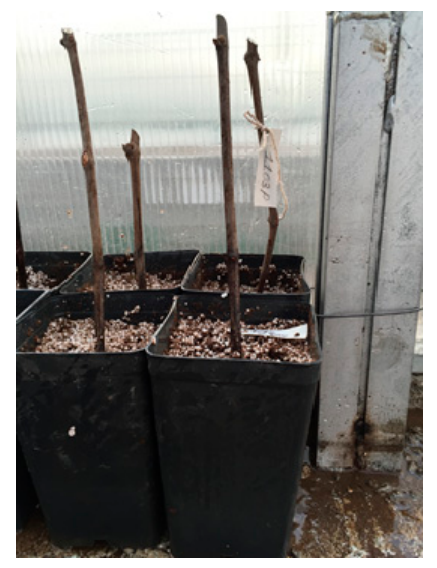

Figure 2. Cuttings belonging to 1103 P rootstock.

\subsubsection{Some Characteristics of 1103 P American Grapevine Rootstock}

Offshoot point is hairy like spider web and pink. Young leaves are hairless and bronze. Ripe leaves are kidney-shaped and petiolar sinus is U-shaped (Figure 3). Their internodes are purple, half-hairy, and have female and sterile flower structure. This rootstock which grows strongly can resist active lime in $17-18 \%$ ratio. It is resistant against $0.6 \mathrm{~g} / \mathrm{kg}$ salt. The rate of its taking inoculation and root is very high [8-11].

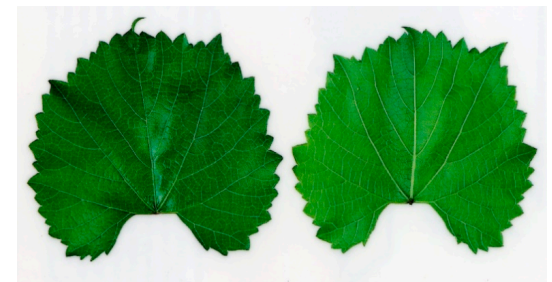

(a)

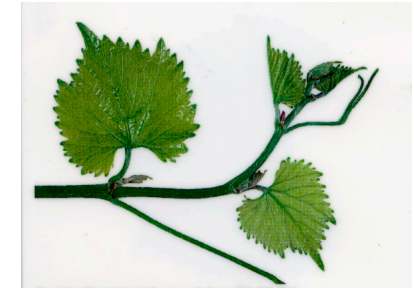

(b)

Figure 3. $1103 \mathrm{P}$ American grapevine rootstock [11]. (a) $1103 \mathrm{p}$ grapevine leaves. (b) $1103 \mathrm{p}$ grapevine shoot. 


\subsubsection{Some Characteristics of 1616 C American Grapevine Rootstock}

Offshoot point is hairy like spider web, young leaves are pale green and hairy like spider web. Ripe leaves have 5 corners and leaf sinus is open, lyre-shaped (Figure 4). It has typical female flower characteristics and cluster small black grains. Yearly bars are pinstriped and internodes are long.

It can grow better in humid soils and its inoculation can accelerate its ripening.

1616 C American grapevine rootstock is pretty durable against phylloxera and its resistance against lime is about $11 \%$ [9].

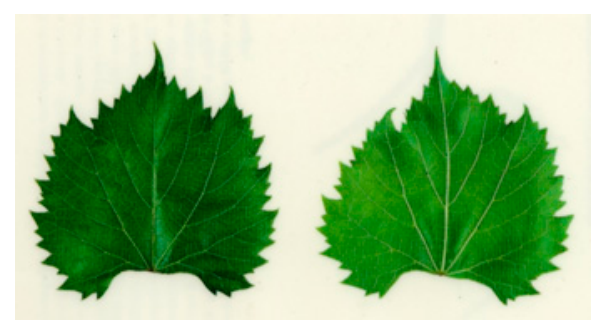

(a)

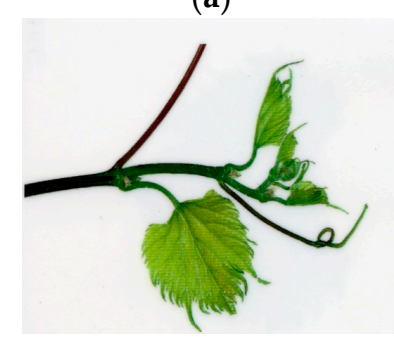

(b)

Figure 4. 1616 C P American grapevine rootstock [11]. (a) 1616 c grapevine leaves. (b) $1616 \mathrm{c}$ grapevine shoot.

\subsection{Method}

\subsubsection{Obtaining the Cuttings, Their Protection and Planting}

$1103 \mathrm{P}$ and $1616 \mathrm{C}$ American grapevine rootstock cuttings used in the experiment were obtained from Manisa Vitivulture Research Station Management. These cuttings were taken from the well-lignified middle parts of one-year-old branches following the defoliation, as Roux reported (1988) [12] Their lengths were adjusted to 30-40 cm according to TS-4027, the ones with 8-12 mm diameter were fastened in bunches of 50 [13] and they were preserved in polyethylene plastic bags in cold storages having $+4{ }^{\circ} \mathrm{C}$ temperature and $95-98 \%$ relative humidity [14].

Pearlite + Peat + garden soil mixture in 1:1:2 proportion was used as the rooting environment. Analysis results belonging to the environment used in rooting was given in Table 1. Rooting environment having been prepared in the stated proportions was scattered among the vases of $14 \times 14 \times 20 \mathrm{~cm}$ sizes, about $1625 \mathrm{~g}$ for each one. The cuttings belonging to the rootstocks which were taken to these rooting vases were planted by blunting the buds and keeping two buds out (on 6 April 2016).

Table 1. Some analysis results belonging to the environment used in rooting.

\begin{tabular}{ccc}
\hline Measure Parameter & Unit & Value \\
\hline Nutrient Media Ph & - & 7.95 \\
$\mathrm{CaCO}_{3}$ proportion in nutrient media & $\%$ & 4.95 \\
Organic Substance Amount in nutrient media & $\%$ & 78.24 \\
Electricity Conductivity in nutrient media & $\mathrm{dsS} / \mathrm{cm}$ & 0.317 \\
\hline
\end{tabular}




\subsubsection{Setting up the Experiment}

The study was supported with the applications on 6 different groups. The cuttings were planted in the vases on 11 April 2016 and they started to shoot stocks on 21 April 2016.

As from 21 April 2016 when grapevine buds completely shot stocks, grapevines were taken out of the greenhouse environment to a field with a northern exposure in order for them to adapt to outside conditions. After being kept here for almost a week, it was transferred to the open space where the experiment would be set up.

The cuttings which were irrigated at regular intervals were also subjected to the necessary cultivation processes. To provide homogeneity for the cuttings having shot stocks, the cutting other than the ones which reached a specific height $(5-10 \mathrm{~cm})$ were cut by pruning and taken away from the cuttings which shot stocks.

\subsubsection{The Application of Fertilization in the Cuttings Used in the Experiment}

Fifteen vases were used for each application—one cutting of shooting stock in each vase-in the experiment which was set up according to randomized blocks experimental design.

The experiment was set up as Control, First Application and Second Application and no application was conducted on the control group. Fertilizer solution in $200 \mathrm{~g} / 100 \mathrm{~L}$ water concentration was applied through the leaf. Fertilizer solution in $100 \mathrm{~g} / 100 \mathrm{~L}$ water concentration was applied through the leaf, and fertilizer solution in $40 \%$ g-water concentration was applied on the root (150 cc/cutting) five times every 10 days starting from 21 July 2016.

$20+20+20+$ ME was used as a fertilizer because it can be implemented from both roots and leaves, which makes the process faster, and because it has basic macro and micro nutrients. The Fertilizer used in the applications was $20+20+20+\mathrm{ME}$ and the plant nutrition elements it contained are given in Table 2.

Table 2. Nutrition element contents of the fertilizer used in the applications.

\begin{tabular}{cc}
\hline Nutrition Element in the Fertilizer & W/W \\
Nitrate Nitrogen & $6 \%$ \\
Ammonium Nitrogen & $5.10 \%$ \\
Urea Nitrogen & $8.90 \%$ \\
Total Nitrogen $(\mathrm{N})$ & $20 \%$ \\
Water Soluble Phosphorpenta $\left(\mathrm{P}_{2} \mathrm{O}_{5}\right)$ & $20 \%$ \\
Water Soluble potassium oxide $\left(\mathrm{K}_{2} \mathrm{O}\right)$ & $20 \%$ \\
Water Soluble Boron(B) (All are EDTA and Chelate) & $0.01 \%$ \\
Water Soluble Copper (Cu) (All are EDTA and Chelate) & $0.006 \%$ \\
Water Soluble Iron (Fe) (All are EDTA and Chelate) & $0.02 \%$ \\
Water Soluble Manganese (Mn) (All are EDTA and Chelate) & $0.02 \%$ \\
Water Soluble (Zn) (All are EDTA and Chelate) & $0.02 \%$ \\
\hline
\end{tabular}

\section{Research Findings}

Grapevine rootstocks taken out of the greenhouse environment were kept waiting until they grew ripe and the applications started on 21 July 2016. These applications were conducted in 5 recurrences at 10 day-intervals. After collecting the data, graphics were separately created for each group.

Height averages of the offshoots in 200 foliar fertilization application (first application) in $1616 \mathrm{C}$ American grapevine rootstock group were measured as $56.2 \mathrm{~cm}$. It was observed that after foliar fertilization was applied on $1616 \mathrm{C}$ American grapevine rootstocks, the offshoots grew between $43 \mathrm{~cm}$ and $25 \mathrm{~cm}$ and the average offshoot growth was $34.4 \mathrm{~cm}$. Forty percent of the offshoots belonging to this rootstock grew over $35 \mathrm{~cm}$ (Figure 5). 
When $20 \%$ root and 100 foliar fertilizer was applied to the same rootstocks (second application), it was observed that the average height of offshoots is $60.3 \mathrm{~cm}$. After the fertilization was applied to $1616 \mathrm{C}$ American grapevine rootstock, it was observed that offshoots grew between $51 \mathrm{~cm}$ and $32 \mathrm{~cm}$ and average growth was $37.9 \mathrm{~cm} 66.6 \%$. $1616 \mathrm{C}$ American grapevine rootstocks showed a growth of over $35 \mathrm{~cm}$.

When the control groups in the same rootstocks were observed, it was determined that the average growth in the offshoots is $59.9 \mathrm{~cm}$. Control group offshoots grew between $40 \mathrm{~cm}$ and $26 \mathrm{~cm}$ and the average growth was $32.1 \mathrm{~cm}$. The $13.3 \%$ of the offshoots belonging to $1616 \mathrm{C}$ American grapevine rootstocks in the control group grew by more than $35 \mathrm{~cm}$.

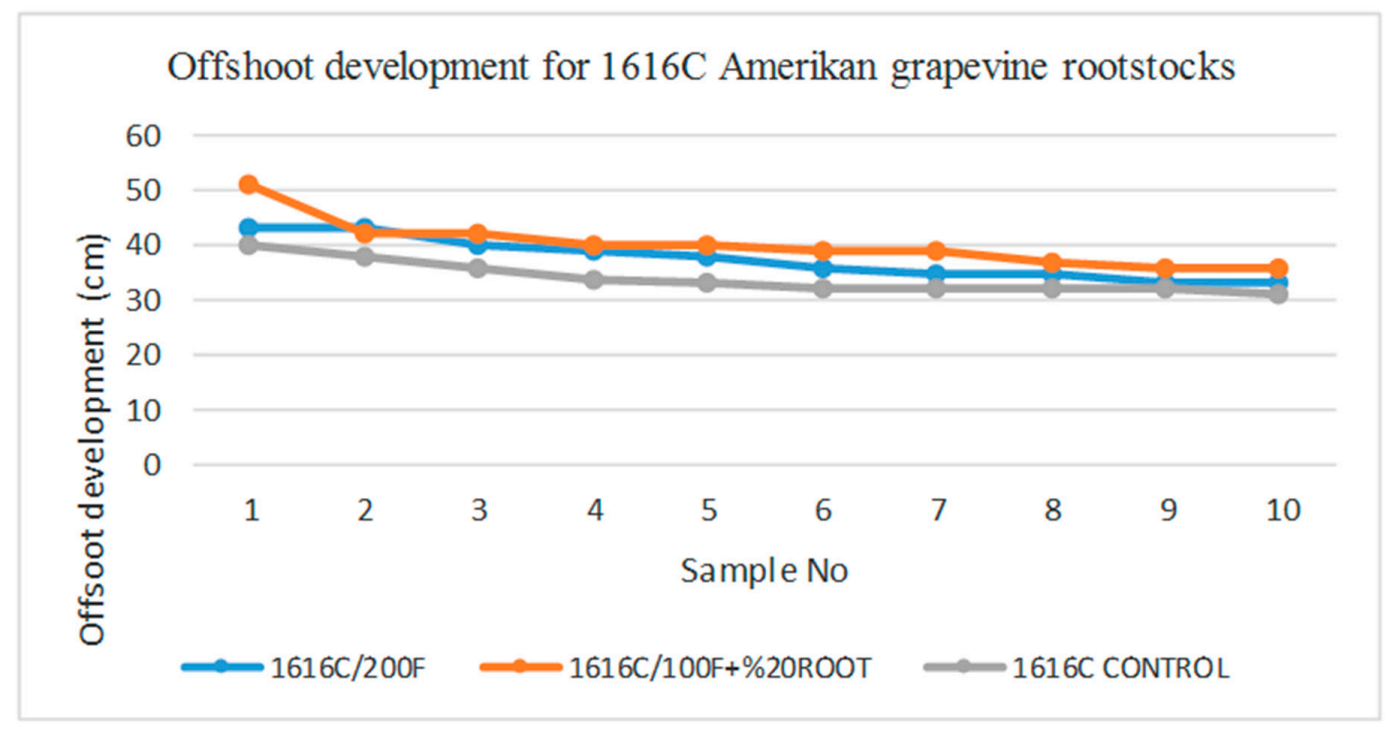

Figure 5. Offshoot development belonging to $1616 \mathrm{C}$ American grapevine rootstocks (Graphics were made by adding the growth amounts to the average height before the application, based on 10 rootstocks which grew the most.)

The height averages of the offshoots that grew in 200 foliar fertilization application (first application) in $1103 \mathrm{P}$ American grapevine rootstock group were $80.5 \mathrm{~cm}$. It was observed that after foliar fertilization was applied on $1103 \mathrm{P}$ American grapevine rootstocks, the offshoots grew between $84.0 \mathrm{~cm}$ and $46.0 \mathrm{~cm}$ and the average offshoot growth was $61.4 \mathrm{~cm}$. The entire offshoot belonging to this rootstock grew by over $35 \mathrm{~cm}$.

When $20 \%$ root and $100 \mathrm{~g} / 100 \mathrm{~L}$ water foliar fertilizer was applied to the same rootstocks (second application), it was observed that the average height of the offshoots is $56.3 \mathrm{~cm}$. After the fertilization was applied to $1103 \mathrm{P}$ American grapevine rootstock, it was observed that the offshoots grew between $57 \mathrm{~cm}$ and $27 \mathrm{~cm}$ and average growth was $39.5 \mathrm{~cm}$. Eighty percent of 1103 P C American grapevine rootstocks showed a growth of over $35 \mathrm{~cm}$.

When the control groups in 1103 P American grapevine rootstocks were taken into consideration, it was determined that the average growth in offshoots was $50.5 \mathrm{~cm}$. The offshoots in the control group grew between $45.0 \mathrm{~cm}$ and $23.0 \mathrm{~cm}$, and $30.6 \mathrm{~cm}$ on average. Only $6.6 \%$ of the offshoots of $1103 \mathrm{P}$ American grapevine rootstocks in the control group grew by over $35 \mathrm{~cm}$ (Figure 6). 


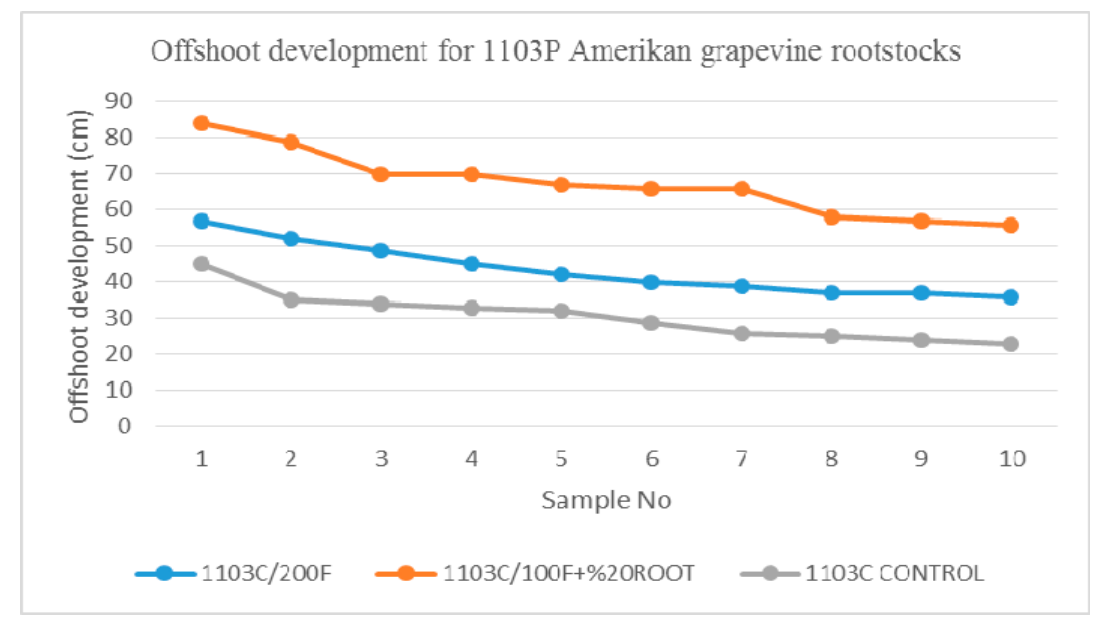

Figure 6. Offshoot development belonging to 1103 P American grapevine rootstocks (Graphics were made by adding the growth amounts to the average height before the application, based on 10 rootstocks which grew the most.)

\section{Discussion and Result}

Green vertical surfaces improve air quality, decrease heat island effect, make a contribution to heat and sound isolation, save energy, help wildlife and give esthetic value, especially in urban areas and one of the major purposes of this study is to help urban areas to be sustainable and livable by determining the characteristics of the grapevine as greenwall plant.

In this study, the growth of grapevine cuttings and the changes in their coverage areas were examined. It was determined that the rootstocks on which $20 \%$ root and $100 \mathrm{~g} / 100 \mathrm{~L}$ water leaf fertilizers were applied showed the best development among the experiment groups. Although $1103 \mathrm{P}$ rootstock showed the best development, it was observed from the footprints (average $61.4 \mathrm{~cm}$ ) that both rootstocks covered the same space (Figure 7). It was also observed that $1616 \mathrm{C}$ rootstock closed the footprint gap at the end of the application, since it showed a better development in the period until fertilization.

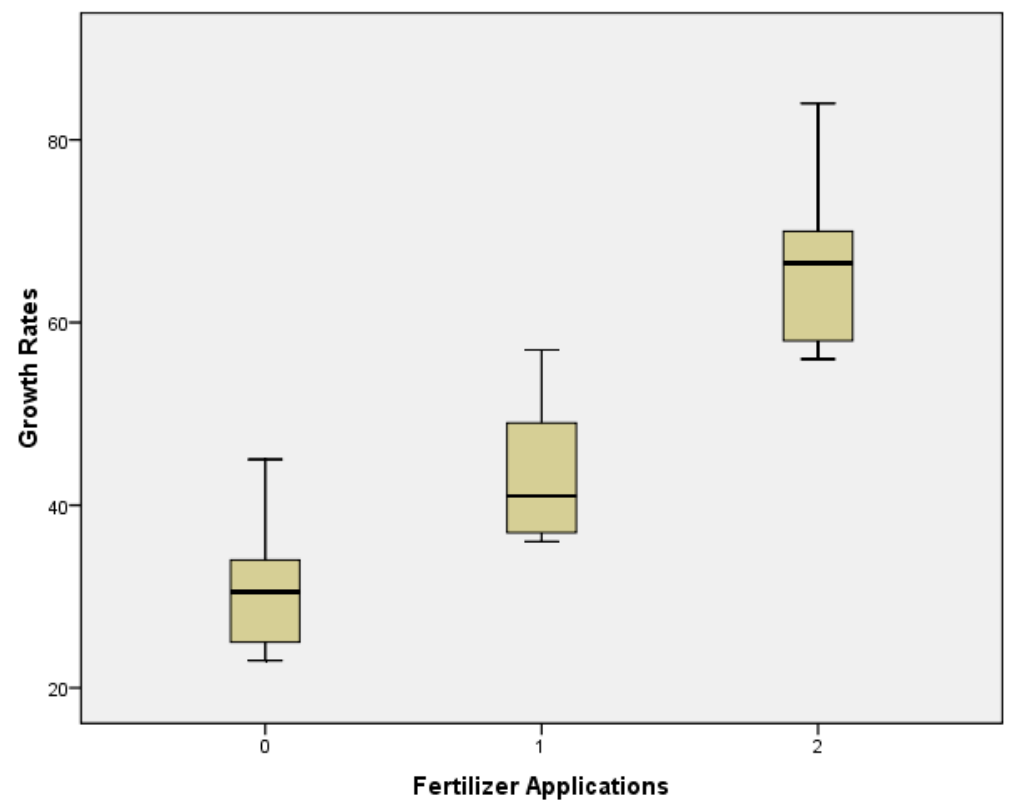

Figure 7. Effects of Fertilization on the Growth Rate of 1616 c grapewine rootstocks. 
To be able to put the values in the database properly, the rootstocks that have no fertilizer applications were marked as 0 , those which have only foliar fertilizer applications were marked as 1 and finally those which have both root and foliar fertilizer applications were marked as 2 .

When focusing on $1103 \mathrm{p}$ rootstocks, according to the $\mathrm{F}$ test that has $95 \%$ Confidence Interval for Mean, the hypothesis can be taken as acceptable with $p=0.000<0.050$. This means there are significant differences between the groups that have different fertilizer applications (Tables 3-5, Figure 8).

Table 3. Statistical analysis for 1103 P American grapevine rootstocks.

\begin{tabular}{|c|c|c|c|c|c|c|c|c|}
\hline \multicolumn{9}{|c|}{ Descriptives } \\
\hline \multicolumn{9}{|c|}{ Growth Rates } \\
\hline & \multirow{2}{*}{$\mathbf{N}$} & \multirow{2}{*}{ Mean } & \multirow{2}{*}{$\begin{array}{c}\text { Std. } \\
\text { Deviation }\end{array}$} & \multirow{2}{*}{$\begin{array}{l}\text { Std. } \\
\text { Error }\end{array}$} & \multicolumn{2}{|c|}{ 95\% Confidence Interval for Mean } & \multirow{2}{*}{ Minimum } & \multirow{2}{*}{ Maximum } \\
\hline & & & & & Lower Bound & Upper Bound & & \\
\hline 0 & 10 & 30.60 & 6.687 & 2.115 & 25.82 & 35.38 & 23 & 45 \\
\hline 1 & 10 & 43.40 & 7.168 & 2.267 & 38.27 & 48.53 & 36 & 57 \\
\hline 2 & 10 & 67.30 & 9.154 & 2.895 & 60.75 & 73.85 & 56 & 84 \\
\hline Total & 30 & 47.10 & 17.179 & 3.136 & 40.69 & 53.51 & 23 & 84 \\
\hline
\end{tabular}

Table 4. One Way Anova test for 1103 p American grapevine rootstocks.

\begin{tabular}{cccccc}
\hline \multicolumn{7}{c}{ ANOVA } \\
\hline \multicolumn{7}{c}{ Growth Rates } \\
\hline & Sum of Squares & df & Mean Square & F & Sig. \\
\hline Between Groups & 6939.00 & 2 & 3469.900 & 57.871 & 0.000 \\
Within Groups & 1618.900 & 27 & 59.959 & & \\
Total & 8558.700 & 29 & & & \\
\hline
\end{tabular}

Table 5. Duncan test for 1103 p American grapevine rootstocks.

\begin{tabular}{|c|c|c|c|c|}
\hline \multicolumn{5}{|c|}{ Growth Rates } \\
\hline \multicolumn{5}{|c|}{ Duncan $^{a}$} \\
\hline \multirow{2}{*}{ Fertilizer Applications } & \multirow{2}{*}{$\mathbf{N}$} & \multicolumn{3}{|c|}{ Subset for alpha $=0.05$} \\
\hline & & 1 & 2 & 3 \\
\hline 0 & 10 & 30.60 & & \\
\hline 1 & 10 & & 43.40 & \\
\hline 2 & 10 & & & 67.30 \\
\hline Sig. & & 1.000 & 1.000 & 1.000 \\
\hline
\end{tabular}

When focusing on $1616 \mathrm{C}$ rootstocks, according to the $\mathrm{F}$ test that has $95 \%$ Confidence Interval for Mean, the hypothesis can be seen as acceptable with $p=0.004<0.050$. However, there is no significant difference in the second group (among the fertilized groups), which has $1616 \mathrm{C}$ rootstocks and is fertilized at a rate of different doses (Tables 6-8).

When evaluating the statistical analyzes, for Bingol where the experiment was conducted, it is more convenient to use $1616 \mathrm{C}$ rootstock when the use of fertilizer is not desired, while it is more convenient to use $1103 \mathrm{P}$ rootstock if fertilizer is to be used, since more space will be covered in this way (Figure 9). 


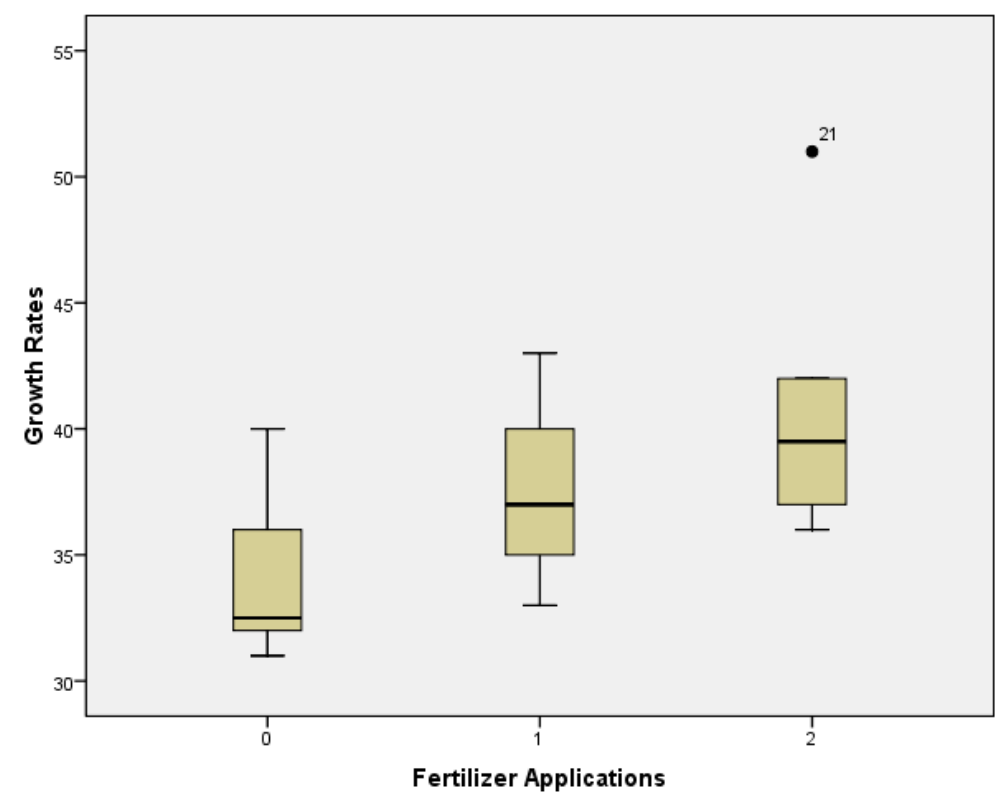

Figure 8. Effects of Fertilization on the Growth Rate of 1103 p grapewine rootstocks.

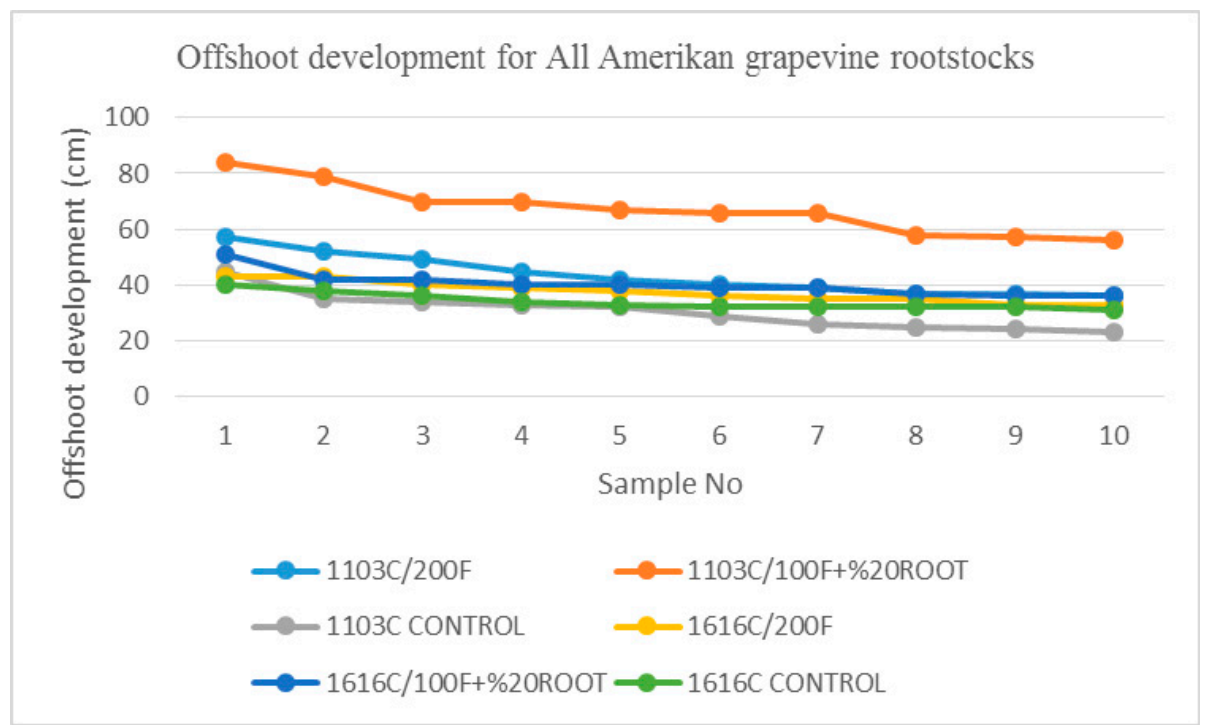

Figure 9. Offshoot development belonging to all American grapevine rootstocks (Graphics were made by adding the growth amounts to the average height before the application, based on 10 rootstocks which grew the most).

According to [7], the most common reasons that make people avoid vertical gardens are:

- Installation cost,

- $\quad$ Extra weight on buildings and walls,

- Damage on buildings and walls by roots,

- $\quad$ Maintenance cost.

However, it is clear that vertical gardens might remove the weight of heat and sound isolators from the buildings and walls as they are already heat and sound isolators. Plus, it is obvious that damage on walls is nearly impossible when a natural climbing plant like a grapevine is used on greenwalls as they take water and nutrients from the soil while they only require pruning. 
Table 6. Statistical analysis for 1616 C American grapevine rootstocks.

\begin{tabular}{|c|c|c|c|c|c|c|c|c|}
\hline \multicolumn{9}{|c|}{ Descriptives } \\
\hline \multicolumn{9}{|c|}{ Growth Rates } \\
\hline & \multirow{2}{*}{$\mathbf{N}$} & \multirow{2}{*}{ Mean } & \multirow{2}{*}{$\begin{array}{c}\text { Std. } \\
\text { Deviation }\end{array}$} & \multirow{2}{*}{$\begin{array}{l}\text { Std. } \\
\text { Error }\end{array}$} & \multicolumn{2}{|c|}{$95 \%$ Confidence Interval for Mean } & \multirow{2}{*}{ Minimum } & \multirow{2}{*}{ Maximum } \\
\hline & & & & & Lower Bound & Upper Bound & & \\
\hline 0 & 10 & 34.00 & 3.018 & 0.955 & 31.84 & 36.16 & 31 & 40 \\
\hline 1 & 10 & 37.50 & 3.719 & 1.176 & 34.84 & 40.16 & 33 & 43 \\
\hline 2 & 10 & 40.20 & 4.367 & 1.381 & 37.08 & 43.32 & 36 & 51 \\
\hline Total & 30 & 37.23 & 4.439 & 0.810 & 35.58 & 38.89 & 31 & 51 \\
\hline
\end{tabular}

Table 7. One Way Anova test for 1616 c American grapevine rootstocks.

\begin{tabular}{cccccc}
\hline \multicolumn{7}{c}{ ANOVA } \\
\hline \multicolumn{7}{c}{ Growth Rates } \\
\hline & Sum of Squares & df & Mean Square & F & Sig. \\
\hline Between Groups & 193.267 & 2 & 96.633 & $6 . .901$ & 0.004 \\
Within Groups & 378.100 & 27 & 14.004 & & \\
Total & 571.367 & 29 & & & \\
\hline
\end{tabular}

Table 8. Duncan test for 1616 c American grapevine rootstocks.

\begin{tabular}{cccc}
\hline \multicolumn{3}{c}{ Growth Rates } \\
\hline \multicolumn{3}{c}{ Duncan $^{\text {a }}$} \\
\hline Fertilizer Applications & $\mathbf{N}$ & \multicolumn{2}{c}{ Subset for Alpha $=\mathbf{0 . 0 5}$} \\
\cline { 3 - 4 } & & $\mathbf{1}$ & $\mathbf{2}$ \\
\hline 0 & 10 & 34.00 & 37.50 \\
1 & 10 & & 40.20 \\
2 & 10 & 1.000 & 0.118 \\
\hline
\end{tabular}

Means for groups in homogeneous subsets are displayed. ${ }^{a}$ Uses Harmonic Mean Sample Size $=10,000$.

As for the cost analysis of vertical green surfaces, it was calculated for the studies done so far that the cost was $40-75 € / \mathrm{m}^{2}$, for the walls supported by wires and knitted wire systems, the cost was about $800 € / \mathrm{m}^{2}$, and for the walls on the surfaces of which boxes were used for the habitat, the cost is $1200 € / \mathrm{m}^{2}$ for living wall systems [15]. This explains another important advantage of using grapevines on greenwalls: maintenance cost is supposed to be low compared with typical high-tech greenwalls because it is possible to give nutrients to grapevines with just irrigation. The cost, along with one-year fertilizer maintenance, was calculated to between $30-40 € / \mathrm{m}^{2}$ for this system (Figure 10) built with American Grapevine Rootstocks (Table 9).

Table 9. Cost per $\mathrm{m}^{2}$ of a grapevine rootstock supportive system for building a green wall.

\begin{tabular}{|c|c|c|c|c|c|c|}
\hline $\begin{array}{c}\text { Item } \\
\text { Number }\end{array}$ & $\begin{array}{c}\text { Pose } \\
\text { Number }\end{array}$ & The Kind of Manufacturing & Unit & Amount & $\begin{array}{c}\text { Unit } \\
\text { Price }(€)\end{array}$ & Price $(€)$ \\
\hline 1 & Y.23.176 & $\begin{array}{l}\text { Making various ironworks from sheet and profile } \\
\text { iron and putting them in their position. }\end{array}$ & $\mathrm{Kg}$ & 5.240 & 2.075 & 10.873 \\
\hline 2 & $04.435 / 10 \mathrm{~A}$ & $\begin{array}{c}\text { Diameter } 5 \times 150 \mathrm{~mm} \text { Mortared anchor (bar) } \\
\text { (stainless cutting 304) }\end{array}$ & Number & 6.000 & 0.12 & 7.82 \\
\hline 3 & 1140 & Flax essence galvanized cutting rope $\left(\varnothing 3 / 4^{\prime \prime}\right)$ & M & 8.000 & 2.33 & 18.64 \\
\hline 4 & ÖBF-1 & American Grape-vine Rootstock Provision & Number & 5.0000 & 0.07 & 0.35 \\
\hline \multirow[t]{2}{*}{5} & ÖBF-2 & Fertilization (One-year cost) & $\mathrm{Kg}$ & 0.198 & 7.81 & 1.54 \\
\hline & & & & & Total: & $39.223 €$ \\
\hline
\end{tabular}




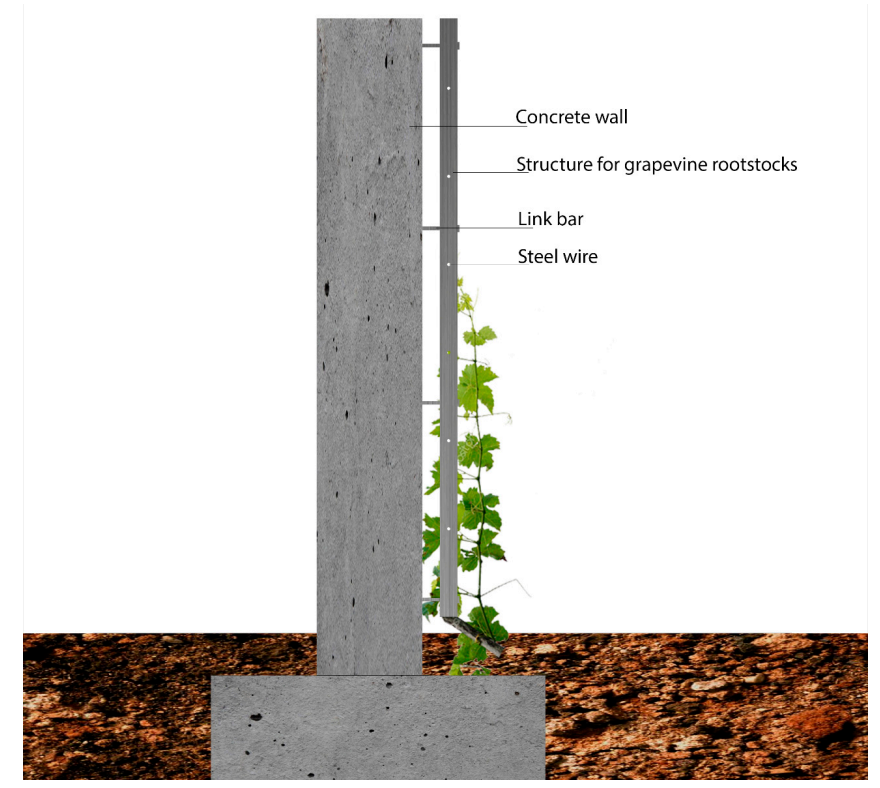

Figure 10. Grapevine rootstock supportive system section for building a green wall.

In spite of the fact that vertical green surfaces have been determined to be extremely important by many scientists, urban planners, landscape architects and several other professionals; it is clear that these vertical habitats are not as common as they should be in many parts of the world. As many people living especially in developing countries often want to see some basic benefits in the short term as soon as they make an investment, these green magical surfaces might sometimes seem to be far removed from their pragmatic perspectives, which could be described as a tough challenge. However, there is no doubt that using edible plants such as grapevines for vertical gardens can create a great support for such people, especially among these countries, which naturally makes a great contribution to sustainable and more livable cities.

Author Contributions: All authors conceived and designed the article. Cakir, Dogan and Meral assembled the database. Yalcinalp, Dogan and Meral conducted the analysis. Cakir, Yalcinalp, Dogan an Meral wrote the article. Cakir and Yalcinalp revised the various drafts. Cakir and Yalcinalp supervised the research.

Conflicts of Interest: The authors declare no conflict of interest.

\section{References}

1. Ecevit, F.M.; ve Kelen, M. Isparta (Atabey)'de Yetiştirilen Uzum Cesitlerinin Ampelografik Ozelliklerinin Belirlenmesi Uzerine Bir Araştırma. Turk. J. Agric. For. 1999, 23, 511-518.

2. Anonymous. Bitkilerde Dogal Renk Maddeleri ve Fenolik Bilesikler. 2006, pp. 1306-7648. Available online: www.teknolojikarastirmalar.com (accessed on 4 November 2016).

3. Ayasligil, Y. Ecology and Natural Distribution of Woody Plants that Can Be Used in Parks and Gardens; Journal of Forest Faculty, Istanbul University: Istanbul, Turkey, 1990; Volume 39.

4. Bass, B.; Baskaran, B. Evaluating Rooftop and Certical Gardens as an Adaptation Strategy for Urban Areas; Institute for Research in Construction: Ottowa, ON, Canada, 2003.

5. Going Vertical: The History of Green Walls. Available online: http://landarchs.com/vertical (accessed on 10 November 2016).

6. Miglietta, P.P.; Leo, F.D.; Massari, S. Water footprint assessment of some Italian wines: A territorial perspective. Int. J. Environ. Policy Decis. Mak. 2015, 1, 320-331. [CrossRef]

7. Meral, A. Peyzaj Mimarligi Kapsaminda Kentsel ve Kirsal Duvar Vejetasyonu ve Ekolojik Karakteristikleri. Master's Thesis, Institute of Science, Karadeniz Technical University, Trabzon, Turkey, 2015. 
8. Galet, P. A Practical Ampelography: Grapevine Identification; Cornell University Press: Ithaca, NY, USA, 1979; p. 245. ISBN 0-8014-1240-4.

9. Celik, S. Bagcllik (Ampeloloji); Anadolu Matbaa Ambalaj San. ve Tic. Ltd. Sti: Tekirdag, Turkey, 1998; Volume 1, p. 426.

10. Çelik, H. Uzum Cesit Katalogu; Mesleki Kitaplar Serisi; Sun Fidan A.S: Ankara, Turkey, 2002; Volume 2.

11. Uzum Cesit Katalogu; Mesleki Kitaplar Serisi; Sun Fidan A.S: Ankara, Turkey, 2006; Volume 2.

12. Roux Le, D.J. The Colection and Storage of Vineyard Grafting Material; VORI Leaflet 209: Stellenbosch, South Africa, 1988; p. 2.

13. Anonymous. Asma Çeliği Standartı; TS 4072: Ankara, Turkey, 1995.

14. Agaoglu, Y.S.; Celik, H. Bazı Amerikan Asma Anaclarında Ethrel Uygulamalari ve Dikim Sekillerinin Koklenme Uzerine Etkileri; Ankara University Ziraat Fakultesi Yıllıg1: Ankara, Turkey, 1978; Volume 27.

15. Perrini, K.; Ottelé, M.; Haas, E.M.; Raiteri, R. Greening the Builging Envelope, Facede Greening and Living wall Systems. Open J. Ecol. 2011, 1, 1-8. [CrossRef]

(C) 2017 by the authors. Licensee MDPI, Basel, Switzerland. This article is an open access article distributed under the terms and conditions of the Creative Commons Attribution (CC BY) license (http:/ / creativecommons.org/licenses/by/4.0/). 